\title{
The Effect of Dramatized Instruction on Speaking Ability of Imam Ali University EFL Learners
}

\author{
Sadegh Khosronejad \\ English Language Department, Foreign Languages Center, Imam Ali University, Tehran, Iran \\ Muhammed Parviz (Corresponding author) \\ English Language Department, Foreign Languages Center, Imam Ali University, Tehran, Iran \\ E-mail:m.p798@yahoo.com
}

Received: 10-05-2013

Accepted: 20-06-2013

Published: 01-09-2013

doi:10.7575/aiac.ijalel.v.2n.5p.87

URL: http://dx.doi.org/10.7575/aiac.ijalel.v.2n.5p.87

\begin{abstract}
Teaching language as a second or foreign language, undoubtedly, is so demanding and seeking to find methods for facilitating this prominent practice whets the appetite of any practitioner who works in this field. Research shows that using drama in the classroom as a means of teaching helps students learn socially, academically, and developmentally. This study was an attempt to determine the effect of dramatized instruction on the speaking ability of EFL learners of Imam Ali University. Sixty EFL male students at the intermediate level participated in the study. Their age range was 19-22. Two instruments were utilized in this study; pretest, and posttest. The data were analyzed through t-test. The data analysis indicated that the mean scores of the experimental group students $(\mathrm{M}=72.80)$ were significantly different $(3.29>2 ; \mathrm{df}=58)$ from the control group students $(\mathrm{M}=65.39)$. In other words, the experimental group outperformed the control group in the posttest significantly. Moreover, the findings indicated that dramatized instruction does have a great effect on the speaking skills. This study supported the idea of effectiveness of dramatized instruction on developing speaking skill and the teachers can help the learners at lower levels promote their speaking skill through dramatized instruction in EFL classes.
\end{abstract}

Key words: Drama, Dramatized Instruction, Conventional Methods

\section{Introduction}

Drama could be defined in a number of ways. It could be seen as an umbrella term covering "a wide range of oral activities that have an element of creativity present" (Hubbard, 1986, p. 317). Susan Holden takes drama to mean any kind of activity where learners are asked either to portray themselves or to portray someone else in an imaginary situation: "in other words, drama is concerned with the world of "let's pretend"; it asks the learner to project himself or herself imaginatively into another situation, outside the classroom, or into the skin and persona of another person" (Holden 1982, p. 1, cited in Davies, 1990). By definition, a drama is a story enacted onstage for a live audience. The word drama comes from the Greek verb dran, which means "to do". Shakespeare puts it "the entire world is a stage" (spoken by the melancholy Jacques in Act II Scene VII), and we the people are the actors on this stage. Therefore, as English teachers why don't we make all the class a stage? Further, there are a number of studies in favor of benefits of drama in foreign and second language learning, such as Maley and Duff (2001), Brumfit (1991) and Phillips (2003), and a great deal of materials to teach languages through drama techniques like Di Pietro (1987), Holden (1981), Kao and O’Neill (1984) and Phillips (2003). More importantly, studies (Phillips, 2003; Miller, 2008; Fleming, 2006; Hillyard, 2010) indicated drama can create entertaining, fun and motivation and can provide different opportunities for the use of language in a context and is also useful in teaching and learning cross-curricular content, etc. In addition, through drama activities the student learns by developing practical "hands-on" skills for applying meaning into real-life situations. (Moghaddas \& Ghafariniae, 2012). This is in perfect point of agreement with the communicative principles of languages teaching. Verriour says "as pedagogical process, drama can provide the means for connection student's emotions and cognition" (1985, p. 150). Moreover, he (1985) suggests that with drama as a teaching technique in the classroom, students' own concerns, interests, and needs are recognized. In educational context, through using drama, an instructor can challenge students to expand their knowledge as it gives the learner an opportunity to take personal trip through kinetic experimental learning. A well-known proverb says "tell me and I will forget; teach me and I will remember; involve me and I will learn". There are so many features in this model of instruction which make it unique for this purpose. In addition, research indicates that using drama in the classroom as a means of teaching helps students learn academically, socially, and developmentally. "The significant kind of learning which is attributable to experience in drama is the growth in the student's understanding about human behavior, themselves and the world they live in" (O’Neill \& Lambert, 1991, p.13). This brief sketch bears significant facts which can contribute to speaking. There is an old Iranian adage that reads," a man's disgrace and grace lies in his speech", so it can be concluded that our speaking ability is unequivocally a representation of our personality and so developing of our 
personality is directly based on this skill and drama may be the best way for developing a language ego which is a broad sense of language competency with speaking competency in its heart and its projection.

We conduct research to understand our field, to learn how to become more effective teachers, and to explain to those outside our field why we use drama as a way to educate students (Wagner, 1976). The purpose of researching drama in education is to find how much it could be efficient in fulfilling teaching objectives. Most of the English students in EFL context who have passed several English courses in different institutes seem not to be able to communicate their own ideas or feelings effectively, no matter with which average mark they have graduated from the said institute. Thus, this made an attempt to determine the effect of the dramatized instruction on the speaking ability of EFL learners of Imam Ali University.

\section{Review of the Related Literature}

The use of drama as a tool for teaching is not new. Historically, both drama and theater have long been recognized as potent means of education and indoctrination. The ways they are used today, however, are new, and they differ in a number of respects from the ways they have been used in the past (McCaslin, 1998). Arts advocates and educators have recently started to explore the use of drama as an integrated way of learning the curriculum. According to Fleming (2006, cited in Moghaddas \& Ghafariniae, 2012) "drama is a learner-centered approach", so it allows learners to become active participants in the learning/teaching process. Research studies (Maley and Duff 2001, cited in Moghaddas \& Ghafariniae, 2012; Phillips, 2003) indicate that drama activities can motivate language learners and teachers. Drama activities let students to communicate in the foreign language including those with limited vocabulary (Aldavero, 2008; Carkin et al., 2008) studied the effects of three genres of drama in Taiwan and found what the students themselves felt:

Students with low proficiency and low confidence can benefit greatly from drama, just like the "good" students. Students can benefit from participating in group work as well as in pairs. Drama provides them with a broad range of opportunities in learning English, and Drama motivates them to learn English and gives them more confidence to learn English( p. 23).

Heldenbrand (2003, cited in Moghaddas \& Ghafariniae, 2012) highlights several advantages of teaching language through drama. He considers it as a funny, relaxed and informal way to learn English. Moreover, he states that drama helps in learning new vocabulary and proper pronunciation and intonation, builds confidence for the learner to speak English, creates atmosphere in the better understanding of culture, motivates the language learner, removes the focus from English textbook and involves the whole person as a total physical activity.

Desiatova (2009) outlines some of the benefits of using drama in the language classrooms as follows:

1. It causes learners in using the language for genuine communication and real life purposes.

2. It makes language learning an active, motivating experience.

3. It gives confidence and self-esteem to learners in using the language spontaneously.

4. It brings the real world into the classroom (problem solving, research, consulting dictionaries, real time and space, cross-curricular content).

5. It helps the students in acquiring the language through play, make-believe and meaningful interaction.

6. It makes the learning items memorable through direct experience and affects emotions with different learning styles.

7. When dramatizing, students make use of all the appropriate channels (sight, hearing, and physical bodies) for the active involvement in the language learning.

8. It stimulates learners' intellect and imagination.

9. It develops students' ability to empathize with others and become better communicators.

10. It helps learners in acquiring the language by focusing on the message not the form of their utterance.

From the preceding quotations we can get to this point of view that dramatized instruction could be a kind of teaching technique which is worthwhile spending some time and energy on and finding out its effects on facilitating language learning, especially in the area of speaking skill. This technique could be a cornerstone for experiencing new ways in teaching and learning practice among practitioners in this field. On the other hand, in an EFL context providing an opportunity for learners to practice the second language communicatively is crucial, since an authentic environment of communication is not easily accessible in this context. Dramatized instruction consists of some innate features that make it possible to experience a real situation in an artificial way, as in a dramatized situation there is a meaningful interaction in a meaningful context. In this context, objective is clear and straight forward, it is not simply to put the word, but it is the projection of expressing feelings, attitudes, believes and emotions which other methodologies may be in short of

\subsection{How Come Utilizing Drama Techniques?}

Although texts and conversations share vocabularies and expressions necessary for learning, they are lifeless words on a page that can neutralize a learner. Wessels believes that using drama activities brings the text books to life by putting imaginations, emotions and feelings of the learners into the process of learning (Wessels, 1987, cited in 
Moghaddas \& Ghafariniae, 2012). Providing language learners the opportunity to put themselves directly in the learning experience setting gives them a good feeling of performing something helpful and hence brings more enthusiasm to the classroom which finally improves their chances of better comprehension. Maley and Duff (1982, $\mathrm{p}$. 15, cited in Moghaddas \& Ghafariniae, 2012), in Drama Techniques in Language Learning, relate drama to "the naughty child who climbs the high walls and ignores the no trespassing sign". Wan Yee Sam (1990, p. 87, cited in Moghaddas \& Ghafariniae, 2012) agrees by stating "drama activities can be used to provide opportunities for students to be involved actively. The activities involve the students' whole personality and not only his mental processes". In fact the small stage in the classroom is a nice preparation for the pupils to face the larger stage known as life.

\section{Research Question}

In keeping with the objective of this study, the following question is to be asked:

Does dramatized instruction as compared with the conventional methods of English language instruction have a statistically significant effect on speaking ability of Imam Ali University EFL learners?

\section{Methodology \\ 4.1 Participants}

The population of this study was Imam Ali University EFL learners who comprised nearly 100 male students between 19 to 22 years old in their last year of the study in this university. They have already passed four courses of general English. In the procedure of accomplishing the research 60 students were randomly selected and through a selection rule, participants were assigned into two groups of 30 students, i.e. an experimental group and a control group.

First, the homogeneity of participants was determined through a standard proficiency test (Key English Test). Based on their scores on the proficiency test, 60 students whose scores were between one standard deviation below and above the mean were selected to take part in the study. Then, they were assigned randomly into the experimental and control groups with 30 participants in each group. Furthermore, in this research, the sex variable was removed because all subjects were male.

\subsection{Design of the Study}

The present study was based on a pretest-posttest design in which two groups were involved, an experimental and a control group. At the beginning of the experiment, the participants in both groups took a pretest which was followed by a treatment stage for the experimental group. After the treatment, in order to see the effectiveness of the treatment in the experimental group, a posttest was administered to these two groups. There were two variables in the study: dramatized instruction as independent variable and speaking ability of Imam Ali University EFL learners as a dependent variable.

\subsection{Instrumentation}

In order to gather the data needed for testing the hypothesis of this research, three sets of tests were utilized by the researcher: a standard general English proficiency test (KET), a pretest and a posttest.

\subsubsection{General language proficiency test (KET)}

This test comprise three papers, paper 1 includes Reading and Writing which consists of 1-5 parts and require different reading skills. This paper carries \%50 of the final marks. Paper 2 includes listening (about 25 minutes) and has five parts and a total possible mark of 25 , thus representing $\% 25$ of the final marks. Paper 3 includes speaking and a total possible mark of 20 is scaled up to 25 , to represent $\% 25$ of the final marks. (Appendix A)

\subsubsection{Pretest and posttest}

A structured interview was used as pretest and posttest. The interview was developed by J. C. Richards (2002, p. 326) to evaluate learners' speaking ability. It consists of fifteen questions. (Appendix C)

\subsubsection{Oral Interview Rating Scale}

In order to score the interviews an Oral Interview Rating Scale (Richards, 2002) including five scales, namely, accent, grammar, vocabulary, fluency and comprehension was used. (Appendix C)

\subsubsection{Oral Proficiency Weighting Table}

The points obtained by each participant in oral interviews were weighted against an Oral Proficiency Weighting Table (Richards) to obtain the final score of each participant. (Appendix C)

\subsection{Procedure}

To fulfill the objectives of the study, first the researchers selected 60 students at the intermediate level. The subjects were homogenized through a standard proficiency test (KET). 60 students whose scores were between one standard deviation below and above the mean were selected to take part in the experiment. Students whose scores were below 72.78 and above 50.30 were selected as the participants of the experimental and control groups. Both of group attended in class for fifteen sessions. In the second procedure, the control group studied the same source which was the text of a military contextualized movie in a conventional way which was taking the scripts from the video and working on the vocabularies and grammar structures. In this process, in the first session of the class the teacher broadcasted the movie for the class and after a brief discussion on the story of the film the dialogue which was supposed to be taught for the experimental group was selected and the text of it was worked on in different point of views. First the introduction of new words, then some grammatical structured were worked on and there were some exercises on the already elaborated 
structures and vocabularies to make new sentences with focusing on them. The same process took place in other sessions. But for experimental group a special procedure was considered. First the method was introduced and with a clip of speech from the film of the Queen, acting by Cate Blanchet the features of a unique acting was elaborated by the teacher then the course started with a pamphlet which introduced five key tips for public speech. The file of this teaching material was downloaded from internet. ${ }^{\text {i }}$ The rationale for choosing this paper was that it provides five important scales for the teacher's judgment during practicing of real work on drama. These five scales included the following items:

1. Having a positive mental attitude

2. Voice projection

3. Eye contact

4. Body language

5. Practice

At the first step for entering practical phase of the working on dramatized instruction a piece of a military series, named the Band of Brothers directed by Tom Hangs and Steven Spielberg which is the story of a company in World War II in the battle of Normandy was chosen and broadcasted for the students. The context and the texts of some significant conversations were worked on and the students were asked to play the role of the actors in the episode. Then they were judged according to the formerly introduced scales. Scripts from high performed interactions in different parts of the film were chosen and worked on separately. The rationale for this activity was that the students practiced speaking skill without focusing on form which is the normal behavior of students at this level. The students were been judged 2 times and the range of their improvement were been judged through the scores and the range of difference in their double performance. In this way the students were motivated and directed to a specified manner of conduction to fulfill their requirements not by focusing on form, but by focusing on macro linguistics elements in a meaningful context. The next phase of the study began with a prepared drama by the Russian author, Leo Tolstoy (Appendix B). The text was introduced to the students and after getting familiar with the characters and comprehending the text they were divided into 6 groups and began to work to play the drama. They were guided by the teacher from different points of view, their pronunciation, and the prosodic features of their utterances and so on. In the next phase a topic was chosen and according to it a drama was prepared by the students with the help of teacher and it was worked on by the students and in the last phase the class was divided to different groups and each group was assigned to prepare a drama according to their personal experiences and creativity. At the end of the course, the subjects in both experimental and control groups were interviewed by two interviewers. In order to check the reliability of the interviewers' or raters' judgment correlation coefficient were adopted. This test was to estimate the degree of relationship between the scores given by the raters to each group in the first and last interview. Finally, in order to test the hypothesis in this study, there was a ttest for determining the statistical significance of the difference between means on two sets of scores.

\section{Data analysis}

The collected data were exposed to various analysis processes. Based on parametric approach the data were analyzed based on correlation analysis, descriptive statistic and respective inferential statistics which mainly included t-tests.

To keep the reliability of the pretest and posttest, the interviews were conducted and rated by two experienced teachers and indicated the correlation of 0.77 which is fairly a significant correlation. The correlation result is shown in Table 4 . 1.

Table 4.1. Correlation is significant at the 0.01 level (2-tailed)

\begin{tabular}{llcc}
\hline & & Pretest & Interviews \\
\hline Rater1 & Pearson Correlation & 1 & .77 \\
& Sig. (2-tailed) & & .00 \\
& $\mathrm{~N}$ & 60 & 60 \\
\hline Rater 2 & Pearson Correlation & .77 & 1 \\
& Sig. (2-tailed) & .00 & \\
& $\mathrm{~N}$ & 60 & 60 \\
\hline
\end{tabular}

After administrating the interview pretest, the descriptive statistics of the pretest scores of the experimental and control group students were carried out. The mean value and standard deviation of the pretest scores was 60.14 and 8.69 for the experimental group students and 62.96 and 9.56 for the control group students, respectively. The descriptive statistics of the pretest scores is shown in Table 4-2.

Table 4.2. Descriptive analysis of pretest scores (in Experimental \& Control Group)

\begin{tabular}{lccccc}
\hline & $\begin{array}{c}\text { Exp(1) } \\
\text { Cont(2) }\end{array}$ & N & Mean & SD & $\begin{array}{c}\text { SE } \\
\text { Mean }\end{array}$ \\
\hline \multirow{2}{*}{ Scores } & 1 & 30 & 60.14 & 8.69 & 1.53 \\
\cline { 2 - 6 } & 2 & 30 & 62.96 & 9.56 & 1.69 \\
\hline
\end{tabular}


The observed $t$-value for the pretest was $-1.23(\mathrm{df}=58)$, which is smaller than 2.00 , i.e. the critical $\mathrm{t}$-value at the same degree of freedom $(-1.23<2.02 ; \mathrm{df}=58)$. According to the results of $\mathrm{t}$-test used to compare the pretest scores of students, no statistically significant difference was found between the pretest scores of the experimental group and the control group students. In other words, the groups were homogenous in terms of their speaking performance at the beginning of the training. The result of the independent t-test for pretest scores is presented in Table 4.3.

Table 4.3 Independent samples t-test for pretest scores

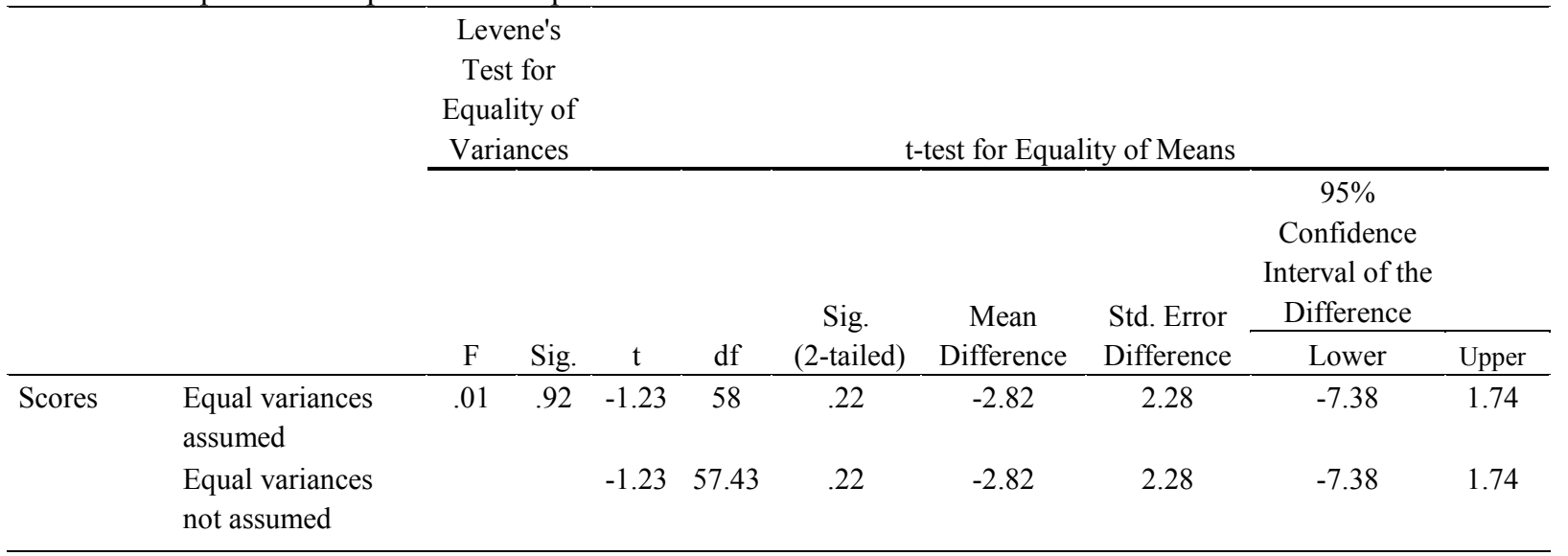

After applying dramatized instruction to the experimental group, but not to the control group per 15 sessions, the posttest was administered to both groups to compare any improvement in the speaking performance of the experimental group with that in the control group at the end of the treatment. The posttest was the parallel form of the pretest, and indicated the correlation of 0.78 which is fairly a significant correlation. The correlation result is shown in Table 4-4.

Table 4.4. Post test correlation

\begin{tabular}{llcc}
\hline & & Posttest & Interviews \\
\hline Rater1 & Pearson Correlation & 1 & .78 \\
& Sig. (2-tailed) & & .00 \\
& $\mathrm{~N}$ & 60 & 60 \\
\hline Rater 2 & Pearson Correlation & .78 & 1 \\
& Sig. (2-tailed) & .00 & \\
& N & 60 & 60 \\
\hline
\end{tabular}

Correlation is significant at the 0.01 level (2-tailed)

The mean value and standard deviation of the experimental group students on the posttest were 72.80 and 8.80 , while the mean value and standard deviation of the control group students were 65.39 and 9.19, respectively. After the experimental and the control group were administrated a posttest, to determine the difference between the means of the posttest scores of the experimental and control group students, an independent t-test was used.

As presented in Table 4.5 below, the observed $\mathrm{t}$-value at the $\mathrm{df}=58$ was 3.29 , which is greater than the critical $\mathrm{t}$-value that equals 2.02 at the same degree of freedom $(\mathrm{df}=58)$. The descriptive statistics of the posttest is presented in Table 45 .

Table 4.5. Descriptive statistics of the speaking posttest scores

\begin{tabular}{cccccc}
\hline & $\begin{array}{c}\text { Exp\& } \\
\text { Cont }\end{array}$ & $\mathrm{N}$ & Mean & Std. Deviation & $\begin{array}{c}\text { Std. Error } \\
\text { Mean }\end{array}$ \\
\hline \multirow{3}{*}{ SCORE } & EXP & 30 & 72.80 & 8.80 & 1.55 \\
\cline { 2 - 6 } & CONT & 30 & 65.39 & 9.19 & 1.62 \\
\hline
\end{tabular}


Table 4.6. Independent sample t-test for the posttest

\begin{tabular}{|c|c|c|c|c|c|c|c|c|c|}
\hline \multirow[t]{3}{*}{$\begin{array}{l}\text { Levene's Test for } \\
\text { Variances }\end{array}$} & \multirow[t]{3}{*}{ L quat } & \multirow[b]{3}{*}{ Sig. } & \multirow[b]{3}{*}{$\mathrm{t}$} & \multicolumn{4}{|c|}{ T-test for Equality of Means } & \multirow{2}{*}{\multicolumn{2}{|c|}{$\begin{array}{l}95 \% \text { Confidence } \\
\text { Interval of the } \\
\text { Difference }\end{array}$}} \\
\hline & & & & & $\begin{array}{l}\text { Sig. } \\
(2-\end{array}$ & $\begin{array}{c}\text { Mean } \\
\text { Differenc }\end{array}$ & Std. Error & & \\
\hline & & & & $\mathrm{df}$ & tailed) & $\mathrm{e}$ & Difference & Lower & Upper \\
\hline $\begin{array}{l}\text { Score Equal } \\
\text { variances }\end{array}$ & .34 & .55 & 3.29 & 58 & .00 & 7.40 & 2.25 & 2.90 & 11.90 \\
\hline assumed & & & & & & & & & \\
\hline $\begin{array}{l}\text { Equal variances not } \\
\text { assumed }\end{array}$ & & & 3.29 & 57.8 & .00 & 7.40 & 2.25 & 2.90 & 11.90 \\
\hline
\end{tabular}

\section{Results}

The present study investigated the effectiveness of dramatized instruction on the speaking ability of Imam Ali University EFL learners. The independent-samples t-test analysis of the pretest scores showed that there was no significant difference $(\mathrm{t}=-1.23<2.02 ; \mathrm{df}=58)$ between the mean scores of the experimental and control group students, i.e. the two groups performed fairly similar to each other in the pretest. Then experimental group received treatment on dramatize instruction, while the other group did not. To compare any improvement in the experimental group's speaking ability with that in the control group at the end of the training, a posttest was administered to participants in the two groups. The analysis of the scores applying the independent samples t-test statistical procedure indicated that the mean scores of the experimental group students $(\mathrm{M}=72.80)$ were significantly different $(3.29>2.02 ; \mathrm{df}=58)$ from the control group students $(M=65.39)$. In other words, there has been a statistically significant difference between the performances of the two groups and the experimental group outperformed the control group in the speaking posttest.

\section{Discussion \& Conclusion}

In order to explore the effect of dramatized instruction on EFL learners' speaking ability, the present study was conducted. Based on the findings of this study and the related literature, drama could be used in promoting speaking ability in different ways. It could also reinforce memory through visual association in the process of performance during acting events. It was noted that through simulation in different contexts problem solving practically was experienced.

According to the results of the statistical analyses used in this experiment, it can be concluded that the idea of effectiveness of dramatized instruction on the speaking ability was supported. Drama can bridge the gap between course-book dialogues and natural usage, and can also help bridge a similar gap between the classroom and real-life situations by providing insights into how to handle tricky situations. Further, drama strengthens the bond between thought and expression in language, provides practice of supra-segmental and para-language, and offers good speaking practice. If drama is considered as a teaching method in the sense of being part of the eclectic approach to language teaching, then it can become a main aid in the acquisition of communicative competence which is the pivotal for speaking ability. Moreover, drama activities facilitate the type of language behavior that should lead to fluency, and if it is accepted that the learners want to learn a language in order to make them understood in the target language, then drama does indeed foster this end. On the other hand, drama could always be extended and used as a starting-point for other activities. The theme can act as a stimulus for discussion or speaking work going far beyond the acting out of scenes. Dramatic activities can thus be integrated into a course, which in turn could lead to them being exploited in terms of the language syllabus, for example the learning of vocabulary, even of structures. Perhaps one of the greatest virtues to be acquired from the use of drama is that students become more self-confident in their use of English language by experiencing the language in operation and real-life situations. The student-centeredness inherent in all dramatic activities also improves students' maturity and motivation, and the physical involvement contained in drama along with the concept of learning language through action is an effective variation on the method of Total Physical Response (TPR) and other holistic approaches and methods to language teaching, where the learner rather than the language or indeed the teacher is at the center of the learning process. Drama in the English language classroom is ultimately indispensable as it provides learners the opportunity to use their own personalities. It draws upon students' natural abilities to imitate and express themselves, and if well-handled should arouse interest and imagination. Moreover, drama can encourage adaptability, fluency, and communicative competence. It places language in context, and by giving learners experience of success in real-life situations it should arm them with confidence for tackling the world outside the classroom.

\subsection{Implications}

The findings of the study have a number of implications for teachers. As noted, speaking skills are not generally considered as skills requiring the use dramatized instruction by most L2 learners and there seems to be a lack of awareness that this type of instruction facilitates the speaking process (Oxford et al., 1990; Cohen, 2000; Vandergrift, 1999). 
English foreign teachers should realize the importance of speaking skill not only as a foundation for second language learning but also as a skill in its own rights and the value of dramatized instruction in developing speaking skill of the EFL learners. This study shows that the teachers can help the learners at lower levels promote their speaking skill through dramatized instruction in EFL classes. They should incorporate dramatized instruction into their skill lessons and train students systematically about what dramatized instruction is , what role does role-playing in a dramatized context plays in learning English, and how these activities can be transferred to other situations. To be able to succeed in training strategies, teachers should be aware of the significance of strategy in speaking skill and their awareness can be enhanced by teacher trainers who are aware of the benefits of dramatized instruction. As Field (1998) pointed out, devoting a certain amount of the class time for helping students approach and settle their problems is an essential part of teaching speaking skill. Therefore, it is crucial for teachers to help students become more aware of their own learning and potential setbacks probably encountered, and develop their ability to cope with the difficulties repeatedly. It can be concluded that the traditional idea of only exposing EFL learners to commercial conventional course books in speaking classes should be put aside. Instead, dramatized instruction program in which authentic contexts of dramatized situations can be embedded to the speaking course should be included in the regular speaking teaching program to help learners become more effective speakers which, ultimately, will enable them to acquire/learn another language more efficiently and more quickly.

\subsection{Implications for Materials Development}

Studies supporting the idea of effectiveness of dramatized instruction on developing speaking skill can persuade teacher trainers, English teachers, course book writers and curriculum designers to be more aware of the benefits of dramatized instruction and to incorporate drama into their lessons, course books and curricula to help learners be aware of the positive and influential features in dramatized instruction, that is learning by doing.

\subsection{Implications for Language Testing}

Since dramatization in teaching speaking focuses on the process of speaking test developer could incorporate the paralinguistic factors of speaking into speaking tests. To be able to assess how learners process the speaking performance, test developers should design speaking tests on the basis of the different sub-skills of speaking instead of selecting some tasks randomly to be included in speaking tests.

\subsection{Suggestions for Further Research}

1. The focus of the present study was on the effect of dramatized instruction on the speaking ability of the EFL learners. A similar study can be done on other skills such as reading comprehension, writing, and listening.

2. This experiment was conducted on intermediate EFL learners. It would be interesting to carry out a similar study with beginners or advanced level learners.

3. The participants in the present study were male EFL learners. It would be interesting to carry out a study on a co-ed group of learners or on female EFL learners.

4. The present study focused on the explicit and direct presentation of dramatized instruction. It would be possible to carry out a study on the indirect and implicit presentation of dramatized instruction.

\section{Reference}

Aldavero, V. A. (2008). Drama in the development of oral spontaneous communication. Encuentro 17. Retrieved on 1/8/2010 from www.encuentrojournal. Org/textos/Alonso.pd.

Carkin, G. (2008) Teaching English Through Drama: The State of the Art.

Davies, P. (1990). The use of Drama in English Language Teaching. TESL Canada Journal/Revue Tesl Du Canada, $8(1)$.

Desialova, L. (2009). Using different forms of drama in EFL classroom. Humanizing Language Teaching Magazine, issue 4 Retrieved on 17/7/2010 from http://www. hltmag.co.uk/aug09/sart07 htm.

Field, P. (1998). The drama classroom: Action reflection, transformation, Routledge/Falmer, London.

Fleming, M. (2006). Drama and language teaching: The relevance of Wittgenstein's concept of language games. Humanizing language teaching Magazine, issue 4 Retrieved on 20/7/2010 from http://www hltmag.co.uk/jul06/mart01. htm.

Hillyard, S. (2010). “ Teaching English through educational drama to students with learning difficulties”. Ministry of Education, Buenos Aires, Argentina.

Hubbard, P. (1986). A Training Course for TEFL. Oxford University Press.

Kao, S. M. (1992). A case study of second language learners' participation in a drama-oriented conversation class. Paper granted by National Science Council, R.O.C.

McCaslin, N. (1998). Creative Drama in the Classroom \& Beyond Studio City, CA: Players Press.

Miller, L. (2008). Innovations in ELT curricula and strategies of implementation in Hong- Kong SAR. Hong Kong, Asia TEFL. 
Moghaddas, B \& Ghafariniae, R. (2012). Applying Drama Techniques in Teaching English in Iran. International Journal of Social Science \& Interdisciplinary Research, 1(9).

O’Neill, C. (1995). Drama worlds: A framework for process drama, Heinemann: Portsmouth, NH.

O'Neill, C \& Lambert, M. (1995). From script to impromptu: Learning a second language through process drama. In P. Taylor and C. Hoepper (Eds.), Selected Readings in drama and theatre education: The IDEA' 95 papers, (pp. 88-101). Brisbane, Australia: National Association for Drama in Education Publications.

Philips, S. C., (2003). Drama with children. Oxford: Oxford University Press.

Verriour, P. (1986b). This issue: Educating through drama. Theory into practice, 24, 150.

Wessels, C. (1987). Drama. Oxford: Oxford University Press.

Wagner, B.J. (1976) Dorothy Heathcote: Drama as a Learning Medium, Hutchison and Company, London.

\section{Appendix (A)}

Pretest and posttest interview for students of IRI Army Cadets

Interview:

1. What is your name?

2. Where do you live?

3. Do you have any brothers or sisters?

4. Does anyone else live at home with you?

5. Now tell me, what do you all do when you get up $\mathrm{n}$ the morning?

6. How do you all go to school and work?

7. Do you have any brothers and sisters in this school?

8. What standard are they in?

9. Which subject do you enjoy most? Why?

10. What do you do at break? Tell me about your best friends.

11. What does your mother cook for dinner?

12. Do you listen to the radio or watch TV?

13. What is your favorite program?

14. Why do you enjoy it most?

15. What do you do when you are getting ready to sleep in the evening?

16. What time do you go to sleep? Why?

17. Look at this picture and tell me what this little boy is doing. Lets' give him a name.

18. What do you suggest? 


\section{Appendix (B)}

\section{The King and the Shirt}

\section{Author: Leo Tolstoy}

\section{Characters: Narrator-Doctor-King-Wiseman1- Wiseman2 - Wiseman 3- Man}

\section{Script:}

Narrator: Once a time in a faraway land, there lived a king who was seriously ill. One day he was lying in bed talking to his doctor.

Doctor: How do you feel today?

King: I have terrible pains. I can hardly eat or sleep... you have to help me.

Doctor: I'm so sorry. I already gave you everything I could.

King: You have to do something! I am getting worse every day. I don't want to die!

Doctor: You have already taken every medicine there is in the kingdom.

King: Yesterday a witch came to see me. She gave me a strange beverage and a green ointment, but I feel worse.

Doctor: I don't know what to say, my king.

King: I am desperate, so I want you to tell all my people, that I will give half of my kingdom to the man who can cure me.

Doctor: I will, but first, let me gather all your wise men ... I know they will know what to do.

King: Very well, talk to them, and do it fast.

Doctor: Yes, my king, I'll be back with an answer.

Narrator: that same day the doctor gathered the wise men to decide how the king could be cured.

Doctor: So what do you think?

Wiseman: did you tried to mix mint with the potion I gave you?

Doctor: I did it, but as you can see ... it didn't work.

Wiseman 2: What about the Sambong?

Doctor: I already told you! Nothing can cure the king!

Wiseman 3: I know what can cure the king .... If you can find a happy many, take off his shirt, put it on the king ... and the king will be cured.

Doctor: Well, even if I don't agree with you ... let's do it. I will tell the king about our decision. Meanwhile, the three of you go now and search for that man.

Narrator: The three men left to search for a happy man. They traveled far and wide, but they could not find a happy man.

Wiseman 1: We are wasting time ... this is not an easy task.

Wiseman 2: All because of you ... there is no o ne who is completely satisfied. We found a man who was healthy, but he didn't have any money.

Wiseman 2: Or of he had children, they were sick.

Wiseman 1: Everyone had something to complain of.

Wiseman 3: We can't give up! I know we will find someone who is completely happy.

Wiseman 1 and 2: If you say so, say.

Wiseman 1: We need to rest ... tomorrow will be another day.

Narrator: The three wise men found shelter in a hut. Next day they continued they journey, and as they were passing by a poor little house, they heard a man talking.

Man: Oh, thank you God, life is beautiful! I have finished my work. I am healthy. I have a loving family and friends. What more could I want?

Narrator: The three wise men turned around to look at the man who was sitting beside the door.

Wiseman 3: I was right

Narrator: But as soon as they approached him, they were surprised.

Wiseman 1: Oh, no!

Wiseman 2: The happy man is so poor ...

Wiseman 3: That he has no shirt! 
Appendix (C)

Oral interview rating scale

\begin{tabular}{|c|c|c|c|}
\hline Scales & Behavioral statement & Points & Interviewee's Status \\
\hline \multirow{6}{*}{ Accent } & Native pronunciation & 6 & \\
\hline & Native like pronunciation & 5 & \\
\hline & Occasional mispronunciation & 4 & \\
\hline & Foreign accent requiring concentrated listening & 3 & \\
\hline & Frequent errors demanding repetition & 2 & \\
\hline & Pronunciation frequently unintelligible & 1 & \\
\hline \multirow{6}{*}{ Grammar } & Almost no error & 6 & \\
\hline & Few insignificant errors only & 5 & \\
\hline & Occasional unremarkable errors & 4 & \\
\hline & Frequent errors causing some misunderstanding & 3 & \\
\hline & Constant errors preventing communication & 2 & \\
\hline & Severe errors making understanding impossible & 1 & \\
\hline \multirow{6}{*}{ Vocabulary } & Appropriate \& extensive use of words & 6 & \\
\hline & Appropriate and adequate vocabulary & 5 & \\
\hline & Occasional use of inappropriate words & 4 & \\
\hline & Frequent use of in appropriate words & 3 & \\
\hline & Constant use of in appropriate words & 2 & \\
\hline & Inadequate basic vocabulary & 1 & \\
\hline \multirow{6}{*}{ Fluency } & Fluent and effortless speech like a native speaker & 6 & \\
\hline & Fluent speech with pauses at unnatural points & 5 & \\
\hline & Fluent speech with occasional problems & 4 & \\
\hline & Fluent problems hindering fluency & 3 & \\
\hline & Slow speech, hesitant, and sometimes silent & 2 & \\
\hline & Virtually unable to make connected sentences & 1 & \\
\hline \multirow{6}{*}{ Comprehension } & Comprehends everything like native speaker & 6 & \\
\hline & Comprehends everything but colloquial or rapid speech & 5 & \\
\hline & Comprehends nearly everything resurveying occasional rephrasing & 4 & \\
\hline & Comprehends short—-than-normal speech & 3 & \\
\hline & Comprehends only slow and simple speech & 2 & \\
\hline & Comprehends very little of even simple \& slow speech & 1 & \\
\hline
\end{tabular}

Oral Proficiency Weighty Table

\begin{tabular}{|c|c|c|c|c|c|c|}
\hline Rating Points & 1 & 2 & 3 & 4 & 5 & 6 \\
\hline Pronunciation & 0 & 1 & 2 & 3 & 4 & 5 \\
\hline Grammar & 6 & 12 & 18 & 24 & 30 & 36 \\
\hline Vocabulary & 4 & 8 & 12 & 16 & 20 & 24 \\
\hline Fluency & 2 & 4 & 6 & 8 & 10 & 12 \\
\hline Comprehension & 4 & 8 & 12 & 15 & 19 & 23 \\
\hline
\end{tabular}

\section{Note}

\footnotetext{
${ }^{\mathrm{i}}$ (www.lauriertoastmasters.co).
} 